\title{
Characterization of camptothecin by analytical methods and determination of anticancer potential against prostate cancer
}

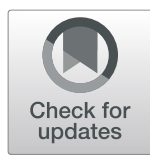

Sunil T. Galatage ${ }^{1^{*}}$ D, Rahul Trivedi ${ }^{2}$ and Durgacharan A. Bhagwat ${ }^{3}$

\begin{abstract}
Background: Objective of present research work is to develop and validate cost-effective analytical tool for determination of camptothecin (CPT) and determine its anticancer potential against prostate cancer LNCaP cell lines. Structural elucidation has been performed by mass spectrometry, Fourier transform infrared spectroscopy, nuclear magnetic resonance spectroscopy, and MTT assay utilized for in vitro cytotoxicity where spectrometric method was used for estimation of camptothecin.

Results: Mass spectra showed peak at 349.2 which matches to standard molecular weight of camptothecin. FTIR and NMR spectra conformed functional moieties and structure of isolated camptothecin which was nearly equal to values mentioned in standard structure of camptothecin. $\mathrm{IC}_{50}$ values of CPT against LNCaP cell lines was found to be $3.561 \mu \mathrm{g} / \mathrm{ml}$. Lambda max of CPT was found to be at $225 \mathrm{~nm}$ and calibration curve found to be linear over the concentration range from 2 to $70 \mathrm{\mu g} / \mathrm{ml}$ of camptothecin. Developed method was found to be linear, accurate, and precise. LOD and LOQ were found to be $0.0524 \mu \mathrm{g} / \mathrm{ml}$ and $0.1614 \mu \mathrm{g} / \mathrm{ml}$, respectively. Developed method has \% relative standard deviation less than one which is reproducible hence \% recovery was found to be $99.80 \%$.

Conclusions: FTIR, NMR, and mass spectrometry results conforms isolated compound was camptothecin; cytotoxicity study proves it has strong potential in treatment of prostate carcinoma as competent alternative to chemotherapy in the form of herbal medicine and the developed UV method proves to be valid, sensitive, and applicable for rapid, accurate, precise, and economical determination of camptothecin.
\end{abstract}

Keywords: Camptothecin, Mass spectrometry, NMR, LNCaP, Anticancer, Accuracy, Precision

\section{Background}

Currently, the world is facing high threat of rapid rise of global cancer, and patients suffering from it badly needed complete cure from cancer [1]. According to globocan, there will be 9.6 million deaths and 18.1 million new cancer patients in 2018 worldwide. Among this, lung cancer is leading cause of mortality and diagnosed about $11.6 \%$ out of total cases. Lung cancer is highest in causing cancer deaths $18.4 \%$ of total carcinoma a death which is closely followed by

\footnotetext{
*Correspondence: gsunil201288@gmail.com

${ }^{1}$ Research Scholar B.R. Nahata College of Pharmacy, Department of

Pharmacy, Mandsaur University, Mandsaur, Madhya Pradesh 458001, India Full list of author information is available at the end of the article
}

breast cancer $11.6 \%$ and prostate cancer $7.1 \%$ for mortality. In men, lung cancer is leading cause of mortality which is subsequently followed by prostate, colorectal, liver, and stomach cancer [2]. Most frequently, surgery, radiation, and chemotherapy have been utilized to cure the carcinoma but it has ample of toxic and adverse effects. From ancient era, wide variety of drugs from natural herbal origin is available which prevent occurrence and cure of cancer [3]. Currently, the demand for herbal-based phytoconstituents is at peak due to its safety, efficacy, and limited side effects in treatment of cancer [4]. Phytoconstituents have unique multimolecular mode of action which potentially responsible to cure cancer
Springer Open (c) The Author(s). 2021 Open Access This article is licensed under a Creative Commons Attribution 4.0 International License, which permits use, sharing, adaptation, distribution and reproduction in any medium or format, as long as you give appropriate credit to the original author(s) and the source, provide a link to the Creative Commons licence, and indicate if changes were made. The images or other third party material in this article are included in the article's Creative Commons licence, unless indicated otherwise in a credit line to the material. If material is not included in the article's Creative Commons licence and your intended use is not permitted by statutory regulation or exceeds the permitted use, you will need to obtain permission directly from the copyright holder. To view a copy of this licence, visit http://creativecommons.org/licenses/by/4.0/. 
along with its versatile pharmacological activities [5]. Nothapodytes nimmoniana is tropical and subtropical plant belongs to Icacinaeae predominantly found in western reason of Maharashtra India. Camptothecin (CPT) is key phytoconstituent of Nothapodytes nimmoniana which is reported to have broad spectrum of pharmacological activities such as antiviral [6], HIV [7], antibacterial, antifungal [8], colorectal cancer, malignancies, ovarian cancer [9-11], and breast cancer [12]. In 1966, Wall ME and Wani MC first identified camptothecin during screening of natural herbal products for anticancer potential. The broad cytotoxic potential of CPT mainly due to its quinoline alkaloid which inhibits DNA enzyme topoisomerase-I is mainly effective against hepatoma, leukemia, and gastric carcinoma along with tumor of head and neck. Chemically, CPT is (S)-4-ethyl-4-hydroxy-1H- pyrano[ $\left[3^{\prime}, 4: 6,6\right]$ indolizino [1,2-b] quinoline-3,14- $(4 \mathrm{H}$, $12 \mathrm{H}$ )-dione. Applicability of CPT in treatment of cancer has ample of limitations such as poor water solubility, low bioavailability, inactivation at physiological $\mathrm{pH}$ by lactone ring hydrolysis and inadequate cellular uptake in acidic media through water soluble carboxylate [13]. Quantification of CPT content from Nothapodytes nimmoniana by different analytical methods like high-performance liquid chromatography (HPLC) [14] and high-performance thin layer chromatography (HPTLC) $[15,16]$. Desorption electro spray ionization mass spectrometry (DESI-MS) $[17,18]$ and proton nuclear magnetic resonance spectroscopy $(1 \mathrm{H}-$ NMR) $[19,20]$ methods have been reported. Normally, CPT was determined and validated by HPLC and RP-HPLC [21, 22] which was costly and consume ample of time; on the other hand, UV method is

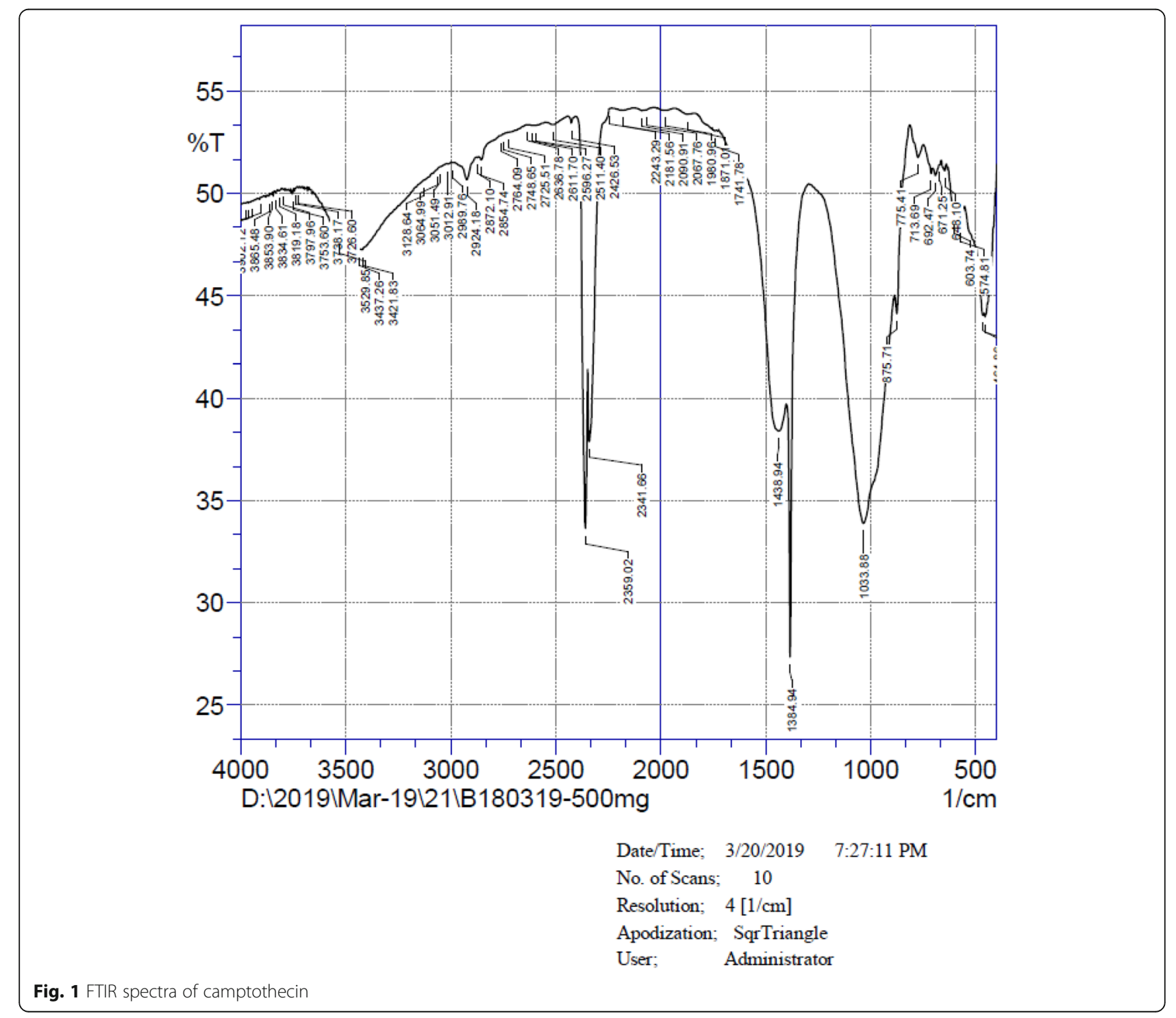


rapid, reproducible, and cost-effective. In this present research work, first attempt has been made to treat prostate cancer with the help of CPT. Till date, there is no valid UV spectroscopic method for determination of camptothecin pure and bulk. The objective of current research work is to determine anticancer potential of CPT against prostate cancer $\mathrm{LNCaP}$ cell lines and to develop and validate cost-effective UV spectroscopic method for determination of camptothecin.

\section{Methods}

\section{Chemicals and reagents}

Standard camptothecin obtained from Aditya Imptex Pvt. Ltd. Mumbai, India. Methanol was supplied by OZONE International. Pvt. Ltd. Mumbai, Maharashtra. Chloroform, sodium carbonate, sulphuric acid, emulgen, and double distilled water were obtained from Unique Chemical Kolhapur. All chemicals and reagents used in the present research work were of analytical grade.

\section{Preparation of extract}

Microwave irradiation method was used for extraction of and isolation of CPT from Nothapodytes nimmoniana leaves using emulgen as surface active agent. Accurately weighted $5 \mathrm{~g}$ of leaf powder and placed in $250 \mathrm{ml}$ conical flask along with $200 \mathrm{ml}$ of emulgen solution having $\mathrm{pH}$ 8. Resulting solution was microwave irradiated for about $1 \mathrm{~min}$ for $350 \mathrm{~V}$ and cooled for 2 min. Resultant solution was maintained at $\mathrm{pH}$ 3-4 by using sulfuric acid and Mayer's reagent added to precipitate CPT $[23,24]$.

\section{Fourier transform infrared spectroscopy (FTIR) study}

FTIR (Perkin Elmer FTIR model-1615) is modern analytical tool which conforms characteristic peaks present in CPT which represents functional groups present and CPT sample was scanned 4000 to $400 \mathrm{~cm}^{-1}$ range at a resolution of $4 \mathrm{~cm}^{-1}$ [25].

\section{Mass spectroscopy}

In mass spectroscopy, LC ion trap method was utilized for determination of ions which are + ve and -ve in mass spectra. For both positive and negative ion mode, capillary voltage was set to $-3800 \mathrm{~V}$ and $4500 \mathrm{~V}$, respectively and at the end \pm 500 volts plate in + ve and -ve ion mode, respectively. With help of syringe, CPT sample was injected along with micro TOF-Q detector and Apollo ESI as ion source. Structural elucidation was confirmed by comparison of isotope and mass accuracy pattern [26].

\section{Nuclear magnetic resonance (NMR) spectroscopy}

Before analysis camptothecin samples were stored at $80{ }^{\circ} \mathrm{C}$. For dissolved sample, solvent was evaporated by stream of nitrogen then redissolved in $\mathrm{CDCl}_{3} / \mathrm{CD}_{3} \mathrm{OD}$ (2:1). A high-resolution NMR spectrum of each single species was acquired on (Bruker DRX $600 \mathrm{MHz}$ ) NMR spectrometer equipped with TXI probe [26].

\section{Cytotoxicity study}

In a micro plate containing 96 wells, cells were seeded which are maintained overnight at $37{ }^{\circ} \mathrm{C}$ in $95 \% \mathrm{RH}$ and $\mathrm{CO}_{2} 5 \%$. Various concentrations ranging from 20 to $0.625 \mu \mathrm{g} / \mathrm{mL}$ of samples was treated. The

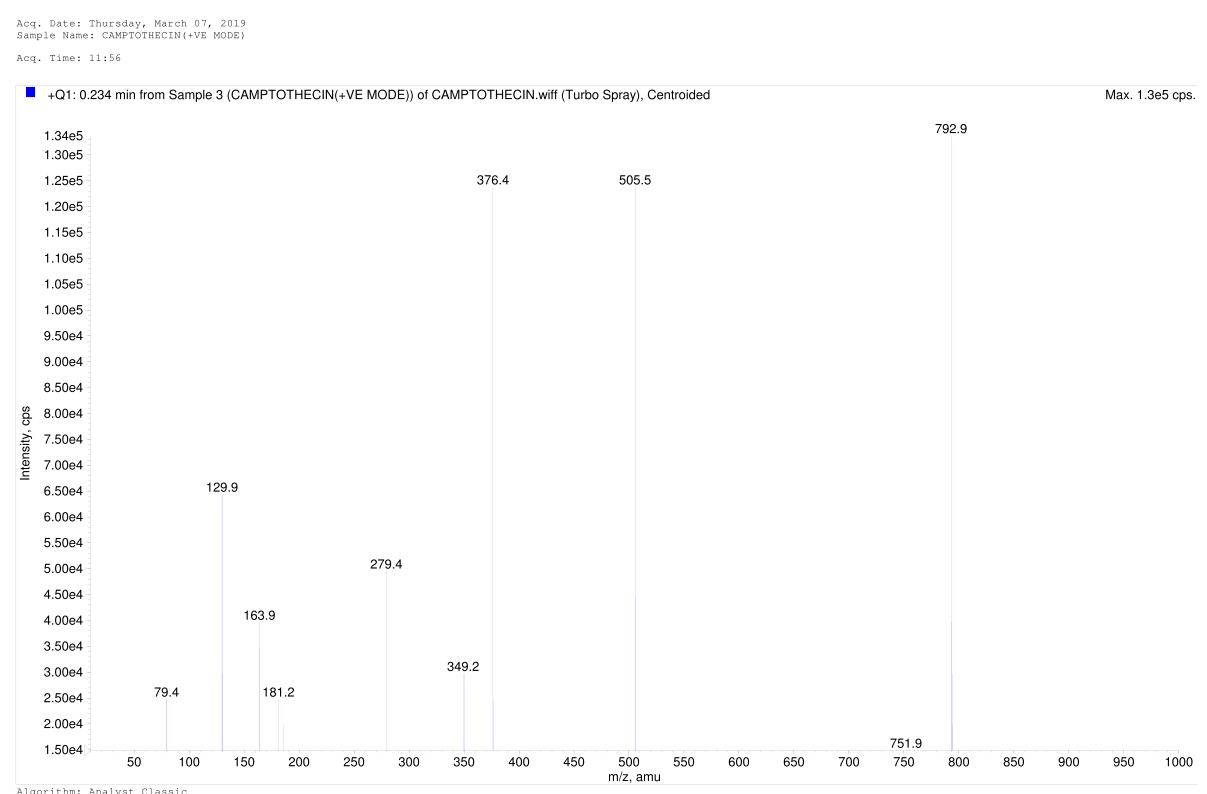

Fig. 2 Mass spectra of isolated camptothecin 
Diya Labs

Camptothecin, 1H-DMSO-d
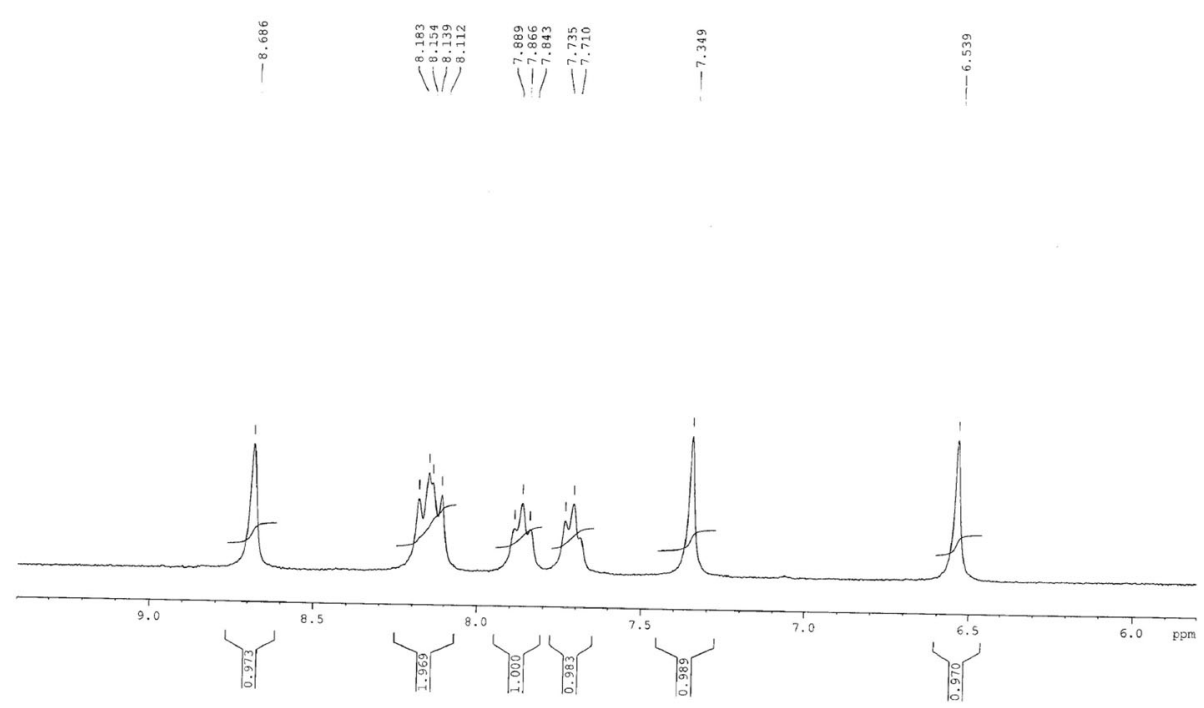

Fig. 3 NMR spectra of camptothecin

cells were incubated for another $48 \mathrm{~h}$. Phosphate buffer used for cleaning of wells and $20 \mu \mathrm{L}$ of the MTT was used as staining solution was poured in every well and incubated at $37{ }^{\circ} \mathrm{C}$. In every single well, DMSO was added after $4 \mathrm{~h}$ which dissolve formazan and with help of micro plate reader and absorbance was measured at $570 \mathrm{~nm}$ [27].

$$
\% \text { Surviving cells }=\frac{\text { Mean OD of test compound }}{\text { Mean OD of Negative control }} \times 100
$$

\section{Standard stock solution}

Precisely weighted camptothecin $10 \mathrm{mg}$ and dissolved in $10 \mathrm{ml}$ of organic solvent methanol and make up the volume up to $100 \mathrm{ml}$ with same solvent. The solution obtained was standard stock solution having the strength of $1000 \mu \mathrm{g} / \mathrm{ml}$. From standard stock solution, $10 \mathrm{ml}$ was withdrawn and $100 \mu \mathrm{g} / \mathrm{ml}$ concentration solution was prepared by suitable dilution which was filtered before analyzing by Whatman filter paper [28].

\section{Calibration curve}

Working solution was prepared by suitably diluting primary stock solution at room temperature. Working solution was serially diluted at different concentrations and scanned in the range of $200-400 \mathrm{~nm}$ (Shimadzu-UV1900). Linearity of calibration curve was measured diluting the working solution in the range of $1-100 \mu \mathrm{g} / \mathrm{ml}$.

\section{Accuracy}

Accuracy of the developed analytical method has been determined by close comparison between actual observed and standard values. Recovery was performed by addition level of 80,100 , and $120 \%$ for test solution in to fixed standard solution [29].

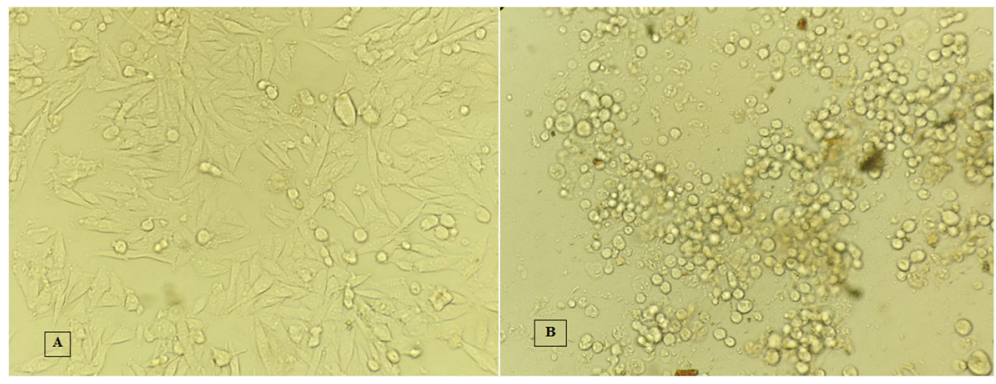

Fig. 4 LNCaP Cell lines. a Untreated. b Treated with CPT 


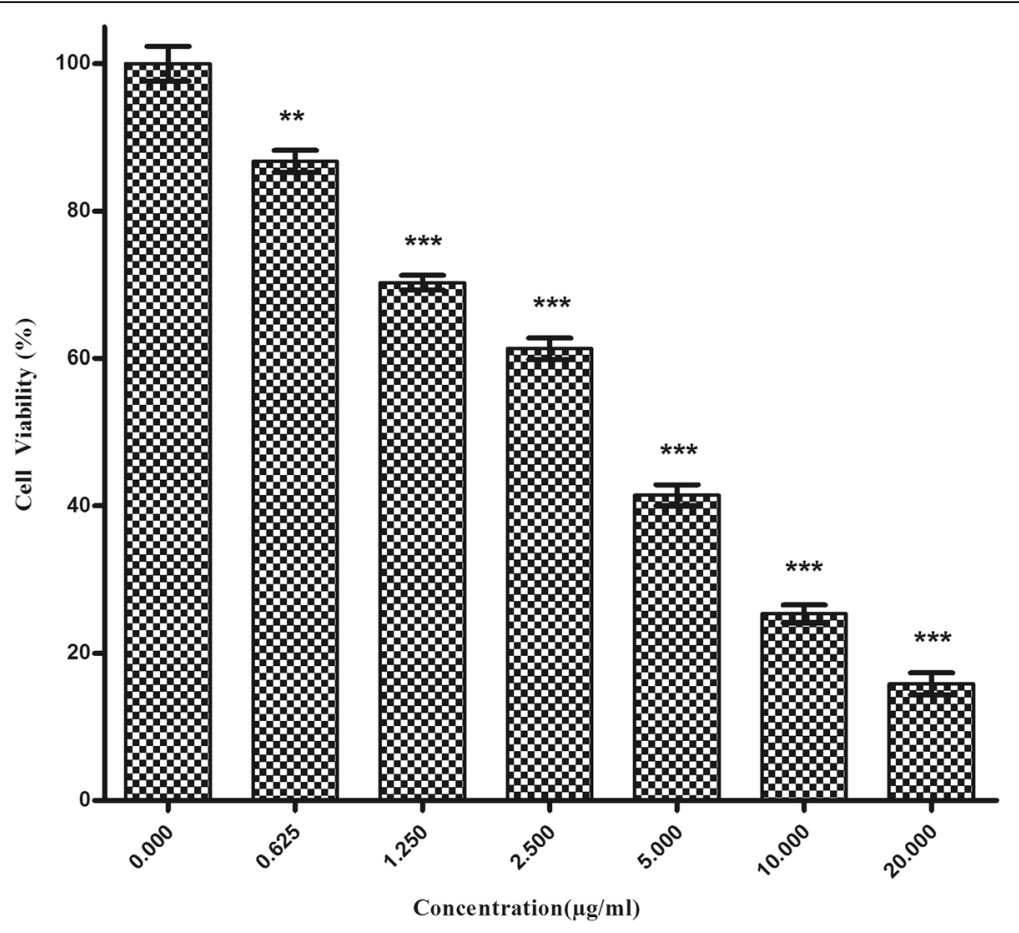

Fig. 5 Cell viability vs concentration on LNCaP cell lines

\section{Precision}

Both intra- and inter-day precision of developed analytical method was confirmed by observed values over a week from present day and on next 3 days at time intervals of $4 \mathrm{~h}$. Observed results were calculated statistically and represented in the form of SD [30].

\section{Repeatability}

By analyzing 6 samples of CPT of $10 \mu \mathrm{g} / \mathrm{ml}$ the repeatability was determined and obtained results further utilized for statistical analysis [31].

\section{Limit of detection and limit of quantification ((LOD and} LOQ)

It is lowest detectible amount measured quantitatively by any analytical method. These variables were determined as per ICH guidelines by observed values along with its SD [32, 33].

LOD and LOQ were calculated using formula LOD $=3.3 * \sigma / \mathrm{s}$ LOQ $=10 * \sigma / \mathrm{s}$

$\boldsymbol{\sigma}$ - Standard deviation and $\mathbf{S}$-slope.

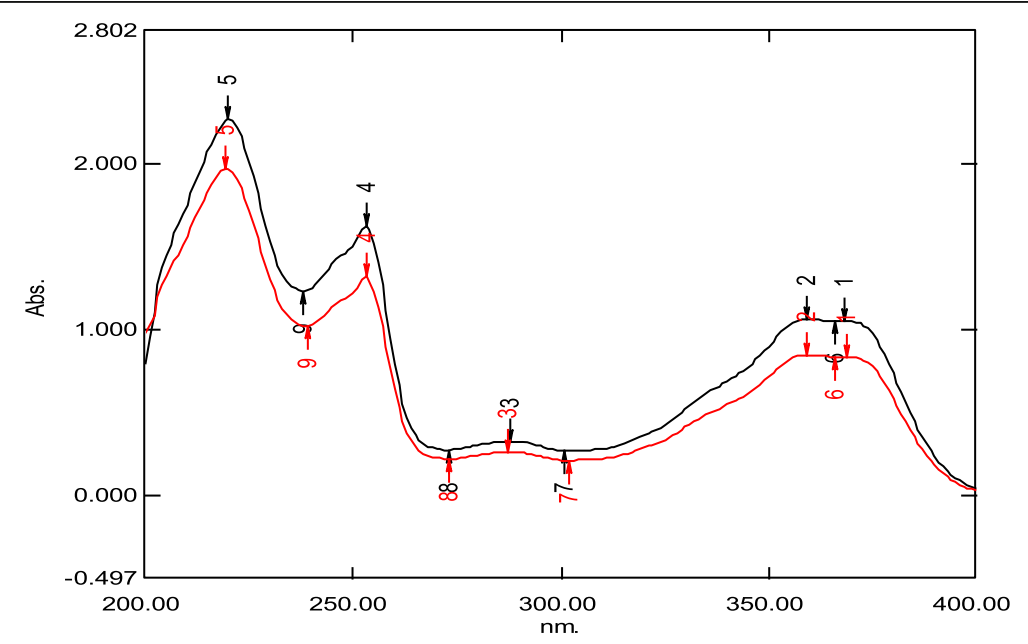

Fig. $\mathbf{6} \boldsymbol{\lambda}$ max of camptothecin 


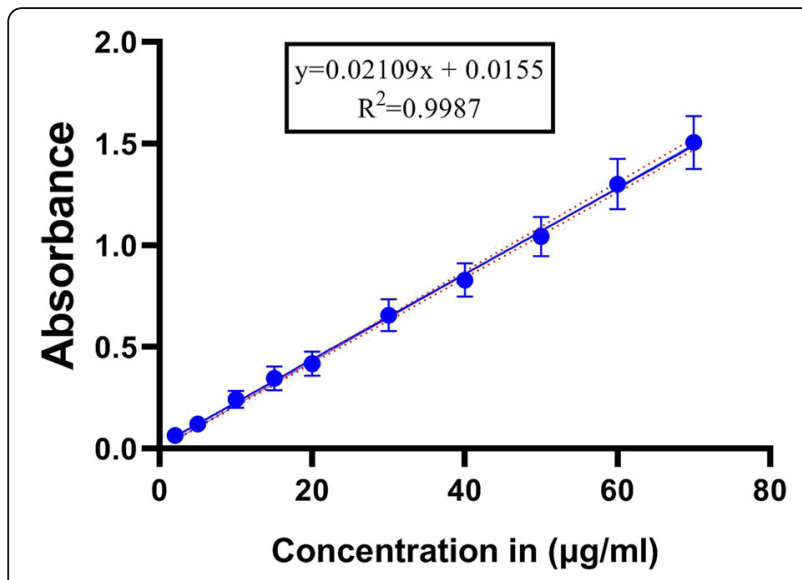

Fig. 7 Calibration curve for camptothecin

\section{Results}

Identification of camptothecin

FTIR spectroscopy

FTIR of CPT from Nothapodytes Nimmoniana extract showed functional peaks related to specific structural features as follows such as, $\mathrm{OH}$ stretching at $3437 \mathrm{~cm}^{-1}$, Ester stretching at $1741 \mathrm{~cm}^{-1}, \mathrm{C}=\mathrm{O}$ stretching at 1642 $\mathrm{cm}^{-1}, \mathrm{C}=\mathrm{C}$ at $1621 \mathrm{~cm}^{-1}, \mathrm{C}=\mathrm{N}$ at $1438 \mathrm{~cm}^{-1}, \mathrm{C}-\mathrm{O}$ at $1033 \mathrm{~cm}^{-1}$ and peak at $775 \mathrm{~cm}^{-1}$ [34]. The values were near or equal to values mentioned in standard structure of camptothecin. Results were shown in Fig. 1.

\section{Mass spectroscopy}

Nothapodytes Nimmoniana is a rich source of the potent alkaloid camptothecin, 9-methoxy camptothecin, 9Methoxy-mappacine-20- $\beta$-glucopyranoside and acetoxycamptothecin-glycoside. It also contains palmitic acid, stearic acid, oleic acid, and linolenic acid. Mass spectroscopy principally determines mass and elemental structures of moieties. Mass spectra of CPT gives precursor $\mathrm{m} / \mathrm{z}$ peak at $349.2[\mathrm{M}+\mathrm{H}]+$ which matches with standard molecular weight of CPT. Hence on the basis of concerned it was conformed that isolated compound was camptothecin [35]. On the other hand, mass spectra gives precursor $\mathrm{m} / \mathrm{z}$ peak at $376.4[\mathrm{M}+\mathrm{H}]+$ and 505.5 $[\mathrm{M}+\mathrm{H}]+$ which more possibly matches with 9-Methoxy camptothecin and 9-Methoxy-mappacine-20- $\beta$-glucopyranoside or Acetoxy-camptothecin-glycoside respectively; precursor $\mathrm{m} / \mathrm{z}$ peak at $792.9[\mathrm{M}+\mathrm{H}]+$ is an unidentified compounds [36] (Fig. 2)

\section{NMR spectra of camptothecin}

NMR spectra of camptothecin showed characteristic peaks at $\mathrm{OH}(1 \mathrm{H})-8.686, \mathrm{~N}-\mathrm{H}(1 \mathrm{H})-8.183$, aromatic protons7.349 to 7.889 , $\mathrm{Ch}(2 \mathrm{H})-5.434$ and $5.279,1 \mathrm{H}\left(\mathrm{CH}_{2}\right)-3.72$ to 3.75 [35, 37]. From this, it was conformed that isolated compound was camptothecin. Results were shown in Fig. 3.

\section{Cytotoxicity study}

Cytotoxic potential of camptothecin on prostate cancer LNCaP cell lines was determined by MTT assay. On morphological evaluation of LNCaP cells in control group appear spindle shape; adhering to neighboring cells. On the other hand, cells treated with CPT lost their normal morphology. Morphological changes in LNCaP cell lines after treatment with CPT shown in Fig. 4. CPT showed concentration dependent \% viability after $48 \mathrm{~h}$ having $\mathrm{IC}_{50}$ value $3.561 \mu \mathrm{g} / \mathrm{ml}$ against $\mathrm{LNCaP}$ prostate cancer cell lines shown in Fig. 5.

\section{Cell viability}

\section{Absorption maxima ( $\lambda$ max)}

Camptothecin showed strong and highest absorption of photon called as $\lambda$ max at $225 \mathrm{~nm}$ as shown in Fig. 6.

\section{Linearity}

Calibration curve of CPT was evaluated by its correlation coefficient. Calibration curve of CPT was found to be linear in the range of $2-70 \mu \mathrm{g} / \mathrm{ml}$. The regression line correlation coefficient $\left(R^{2}\right)$ was calculated and found to be 0.9987 which is closest to 1 and indicative of good linearity of calibration curve with a $y$-intercept of 0.0155 . Slope of the linearity was found to be 0.02109 . Concerned results conformed linearity of calibration curve of CPT through the selected range. Results were shown in Fig. 7.

\section{Precision}

Inter- and intra-day precision study was performed for three continuous days. The $\%$ RSD was fond to be in the

Table 1 Results for intra-day and inter-day precision of camptothecin

\begin{tabular}{|c|c|c|c|c|c|c|c|}
\hline Drug & Conc. $(\mu \mathrm{g} / \mathrm{ml})$ & Intra-day mean abs. & Absorbance \pm S.D. & $\%$ RSD & Inter-day mean abs. & Absorbance \pm S.D. & \%R.S.D \\
\hline \multirow[t]{3}{*}{$\overline{\mathrm{CPT}}$} & 15 & 0.3468 & \pm 0.0016 & 0.503 & 0.3452 & \pm 0.0015 & 0.336 \\
\hline & 30 & 0.6238 & \pm 0.0017 & 0.288 & 0.6368 & \pm 0.0018 & 0.328 \\
\hline & 60 & 1.3024 & \pm 0.0024 & 0.272 & 1.3052 & \pm 0.0023 & 0.313 \\
\hline Mean \%RSD & & & & 0.354 & & & 0.326 \\
\hline
\end{tabular}


Table 2 Data showing repeatability of absorbances

\begin{tabular}{lllll}
\hline Sr. no. & $\begin{array}{l}\text { Concentration } \\
(\boldsymbol{\mu g} / \mathbf{m l})\end{array}$ & Absorbance & Mean \pm S.D. & \%R.S.D \\
\hline $\mathbf{1}$ & 10 & 0.2430 & $0.2421 \pm 0.0037$ & 0.521 \\
$\mathbf{2}$ & & 0.2428 & & \\
$\mathbf{3}$ & & 0.2418 & & \\
$\mathbf{4}$ & & 0.2421 & & \\
$\mathbf{5}$ & & 0.2415 & & \\
$\mathbf{6}$ & & 0.2419 & & \\
\hline
\end{tabular}

S.D standard deviation, R.S.D relative standard deviation

range of $0.272-0.503$ as shown in Table 1 . This confirms the reproducibility of the developed method.

\section{Repeatability}

The repeatability of developed UV method was found to be significant for routine and frequent analysis of camptothecin in pure, bulk, and pharmaceuticals. A result of repeatability study confirms that absorbance remains unaffected on repetition of developed method (Table 2).

\section{Accuracy}

To ensure the accuracy of developed method, recovery study was performed by standard addition method at $80 \%, 100 \%$, and $120 \%$ levels of CPT concentration. The results for the recovery study were found in the desired limits as shown in Table 3.

\section{Discussion}

Structural elucidation of camptothecin has been performed and conformed by different analytical techniques where peaks in FTIR spectra nearly equal to standard CPT [34]. Molecular mass of compound which is most crucial parameter in identification of isolated moiety was determined by mass spectroscopy. Molecular weight isolated CPT exactly matches with standard molecular weight of camptothecin, i.e., 349.2 [35, 36]. NMR spectroscopy mainly determines structure of specific compound. NMR spectra of CPT showed region of delta 8.686 to 5.279 the signals of $\mathrm{H}-7$ related to structural features similar to standard camptothecin $[35,37]$. It is of vital importance to evaluate the cytotoxicity of the CPT for determination of its broad spectrum anticancer potential. Cell viability of CPT on LNCaP prostate cancer exhibit concentration-dependent cytotoxicity having

Table 3 Accuracy measurement by \% recovery method

\begin{tabular}{llllll}
\hline $\begin{array}{l}\text { Standard } \\
\text { CPT }(\boldsymbol{\mu g} / \\
\mathbf{m l})\end{array}$ & $\begin{array}{l}\text { Level of } \\
\text { addition } \\
(\%)\end{array}$ & $\begin{array}{l}\text { CPT } \\
\text { added } \\
(\boldsymbol{\mu} \mathbf{g} / \mathbf{m l})\end{array}$ & $\begin{array}{l}\text { Amount } \\
\text { recovered } \\
(\boldsymbol{\mu g} / \mathbf{m l})\end{array}$ & $\begin{array}{l}\text { Recovery } \\
\text { Recovery }\end{array}$ & $\begin{array}{l}\text { Average\% } \\
\text { recovery }\end{array}$ \\
\hline 05 & 80 & 8 & 12.97 & 99.77 & 99.80 \\
05 & 100 & 10 & 14.98 & 99.87 & \\
05 & 120 & 12 & 16.96 & 99.76 & \\
\hline
\end{tabular}

$\mathrm{IC}_{50}$ values $3.561 \mu \mathrm{g} / \mathrm{ml}$. Drastic changes in morphology conformed that CPT has powerful cytotoxic activity against LNCaP cell lines which was proved by low cytotoxicity value. Normal cells showing higher confluency of monolayer and cells are adhering to the neighboring cells Fig. 4a. In contrast, CPT-treated LNCaP cells seems to be smaller in size, shrank, some cells became spherical, irregular in shape, and showed more significant reduction in the number along with detachment from the adherent site as shown in Fig. 4b [38]. The absorption maxima, i.e., lambda max of $\mathrm{CPT}$, was found to be at $225 \mathrm{~nm}$ and calibration curve found to be linear over the range of $2-70 \mu \mathrm{g} / \mathrm{ml}$. The correlation coefficient $\left(R^{2}\right)$ was found to be 0.9987 which mainly indicative of functional relationship among variables. Results of precision indicate that developed analytical method is reliable, repeatable, and reproducible and can be applied for the determination of CPT in pure, bulk, and pharmaceuticals. Recovery results indicate the absence of interferences from the commonly encountered additives, excipients, and values of mean recovery were found to be $99.80 \%$. High value of molar absorptivity by developed method $6.8252 * 10^{4} \mathrm{~L} / \mathrm{mol} . \mathrm{cm}$ which is indicative of CPT was strongly and potentially absorbed at specific wavelength, i.e., at lambda max. \% RSD was found to be less than one and LOD and LOQ values were found to be $0.0524 \mu \mathrm{g} / \mathrm{ml}$ and $0.1614 \mu \mathrm{g} / \mathrm{ml}$, respectively, which conforms CPT can be determined at lowest possible concentration in pure, bulk, and pharmaceuticals.

\section{Conclusion}

Structural determination by FTIR, NMR, and mass spectrometry confirms that isolated compound was camptothecin; cytotoxicity study proves it has great potential in treatment of prostate cancer as competent alternative to chemotherapy in the form of herbal medicine having $\mathrm{IC}_{50}$ values $3.561 \mu \mathrm{g} / \mathrm{ml}$ against $\mathrm{LNCaP}$ cell lines. As concern to results of accuracy, precision, repeatability, and recovery, it was concluded that developed method proved to be valid, sensitive, and applicable for rapid, accurate, precise, and economical determination of camptothecin in pure, bulk, and pharmaceuticals.

\footnotetext{
Abbreviations

UV: Ultraviolet; DMSO: Dimethyl-sulfoxide; nm: Nanometer; $\mu \mathrm{g}$ : Microgram; ICH: International Conference of Harmonization.; \% RSD: Percent Relative Standard Deviation; $\lambda$ max: Lambda maximum; S.D: Standard deviation; I.P: Indian Pharmacopeia; CPT: Camptothecin; FTIR: Fourier transform infrared spectroscopy; MS: Mass spectroscopy; O.D: Optical density; NMR: Nuclear magnetic resonance; RSD: Relative standard deviation; Surviving cells (\%): Cell viability; Mean OD of test compound: Mean optical density of test compound; Mean OD of negative control: Mean optical density of negative control

\section{Acknowledgements}

The authors are thankful to Department of Pharmacy, Mandsaur University Mandsaur, Madhya Pradesh, Principal B.R. Nahata College of Pharmacy Mandsaur University Mandsaur for providing required guidance and support,
} 
Diya Labs Mumbai for Characterization of camptothecin and Dr. Madhukar Bachulkar for authentification of Nothapodytes nimmoniana. Authors are also thankful to NCBI Pune for providing Prostate Cancer LNCaP Cell Lines and Maratha Mandal Dental College and Research Center Belagavi, for anticancer activity.

\section{Plant authentication}

The whole plant Nothapodytes nimmoniana specimen sample Family (Icacinaeae) was collected from Ajara Forest Resion and identified and authenticated by Dr. Madhukar Bachulkar, Taxonomist Shivaji University Kolhapur, Maharashtra, India, and the voucher specimen No.SGMCP/PH.COG/ HERB/09-2019 herbarium was deposited in pharmacognosy department.

\section{Authors' contributions}

SG is a research scholar who contributed in concept, isolation, design of work, and determination of CPT and SG has major contributions in writing the manuscript. RT and DB were supervisors who contributed in research guidance and have major contribution in monitoring anticancer studies and discussion. All authors read and approved the final manuscript.

\section{Funding}

No funding was obtained for this study.

\section{Availability of data and materials}

The data sets used and/or analyzed during current research work are available from the corresponding author on reasonable request.

\section{Declarations}

Ethics approval and consent to participate

Not applicable

\section{Consent for publication}

Not applicable.

\section{Competing interests}

The authors declare that they do not have any competing interests.

\section{Author details}

${ }^{1}$ Research Scholar B.R. Nahata College of Pharmacy, Department of Pharmacy, Mandsaur University, Mandsaur, Madhya Pradesh 458001, India. ${ }^{2}$ B.R. Nahata College of Pharmacy, Department of Pharmacy, Mandsaur University, Mandsaur, Madhya Pradesh 458001, India. ${ }^{3}$ Bharati Vidyapeeth College of Pharmacy, Near Chitranagari, Morewadi, Kolhapur, Maharashtra 416013, India.

Received: 12 August 2020 Accepted: 29 March 2021

Published online: 22 May 2021

\section{References}

1. Nagai H, Kim YH (2017) Cancer prevention from the perspective of global cancer burden patterns. J Thorac Dis 9:448-451

2. Bray F, Ferlay J, Soerjomataram I, Siegel RL, Torre LA, Jemal A (2018) Global cancer statistics 2018: GLOBOCAN estimates of incidence and mortality worldwide for 36 cancers in 185 countries. CA 68(6):394-424

3. Nadaf SJ, Killedar SG (2018) Curcumin nanocochleates: use of design of experiments,solid state characterization, in vitro apoptosis and cytotoxicity against breast cancer MCF-7 cells. J Drug Deliver Sci Technol 47:337-350

4. Yeap SK, Abu N, Mohamad NE, Tan SW, Alitheen NB (2015) Chemopreventive and immunomodulatory effects of Murraya koenigi aqueous extract on 4T1 breast cancer cell-challenged mice. BMC Complement Alternative Med 15:306

5. Javed I, Banzeer AA, Tariq M, Sobia K, Barkat A, Shah SA, Khalil AT (2017) Plantderived anticancer agents: a green anticancer approach. Asian Pac J Trop Biomed 7:1129-1150

6. Xing K, Justin W, Jang-Hann (2017) Antiviral screen identifies EV71 inhibitors and reveals camptothecin-target, DNA topoisomerase 1 as a novel EV71 host factor. Antiviral Research 143:122-133

7. Li Y-Y, Chen S-W, Liu-Meng (2010) The anti-HIV actions of 7- and 10substituted camptothecins. Molecules 15:138-148
8. Dong Q, Luo J, Qiu W (2016) Inhibitory effect of camptothecin against rice bacterial brown stripe pathogen Acidovorax avenae subsp. avenae RS-2. Molecules 21:978

9. Pommier $Y$ (2011) DNA topoisomerases and cancer, vol 18, pp 1-7

10. Pommier $Y$ (2006) Topoisomerase I inhibitors: camptothecins and beyond. Nat Rev Cancer 19:789-802

11. Pommier $Y$ (2013) Drugging topoisomerases: lessons and challenges. ACS Chem Biol 8:82-95

12. Cinzia T, Simonsen AK, Andersen MB (2019) Topoisomerase I activity and sensitivity to camptothecin in breast cancer-derived cells: a comparative study. BMC Cancer 19:1158

13. Buchi NN, Saisrianusha V, Chandrapriyanka B (2016) Development of Validated Stability Indicating RP-HPLC-PDA Method for Camptothecin Analysis. J Appl Pharm Sci 6(09):140-146

14. Namdeo AG, Sharma A, Fulzele DP, Mahadik KR (2010) Influence of geographical and climatic conditions on camptothecin content of Nothapodytes nimmoniana. Rec Nat Prod 4:64-171

15. Fulzele DP, Satdive RK (2005) Distribution of anticancer drug CPT in Nothapodytes foetida. Fitoterapia 76:643-648

16. Namdeo AG, Sharma A, Sathiyanarayanan L, Fulzele DP, Mahadik KR (2009) HPTLC densitometric evaluation of tissue culture extracts of Nothapodytes foetida compared to conventional extracts for camptothecin content and antimicrobial activity. Planta Med 75:1-7

17. Puri SC, Handa G, Gupta RK, Srivastavam TN, Somal P, Sharma SN (1999) Quantitation of CPT in Nothapodytes foetida. J Indian Chem Soc 76:370-371

18. Mingzhang A, Jing W, Yue S, Wentao G, Longjiang Y (2011) Camptothecin distribution and content in Nothapodytes nimmoniana. Nat Prod Commun 6(2):197-200

19. Srimany $A$, Ifa DR, Naik HR, Bhat $V$, Cooks RG, Pradeep $T$ (2011) Direct analysis of camptothecin from Nothapodytes nimmoniana by desorption electrospray ionization mass spectrometry (DESI-MS). Analyst 136(15):30663068

20. Li CY, Lin CH, Wu TS (2005) Quantitative analysis of camptothecin derivatives in Nothapodytes foetida using $1 \mathrm{H}-\mathrm{NMR}$ method. Chem Pharm Bull Tokyo 53(3):347-349

21. Namdeo AG, Sharma A (2012) HPLC analysis of camptothecin content in various parts of Nothapodytes foetida collected on different periods. Asian Pac J Trop Biomed 2(5):389-393

22. Nalluri BN, Saisrianusha V, Chandrapriyanka B (2016) Development of validated stability indicating RP-HPLC-PDA method for camptothecin analysis. J Appl Pharmaceutical Sci 6(09):140-146

23. Mishra U, Murthy PN, Pasa G, Kumar S (2011) Formulation development and standardization of herbal gel containing methanolic extract of Butea frontosa. Int Res J Pharm 2(11):126-129

24. Uma G, Balasubramaniam V (2012) GC-MS analysis of Nothapodytes nimmoniana [J. Graham] mabberly leaves. J Chem Pharm Res. 4(9):4417-4419

25. Bhaishaikh IM, Galatage ST (2019) Floating microsponges as gastro retentive drug delivery system containing lafutidine to treat gastric ulcer.Acta scientific pharmaceutical sciences, vol 32, pp 3-12

26. Negi A, Sharma N, Singh MF (2012) Formulation and evaluation of an herbal anti-inflammatory gel containing Eupatorium leaves extract. J Pharmacognosy Phytochem 1(4):112-117

27. Kumbar VM, Peram MR, Kugaji MS, Shah T, Patil SP, Muddapur UM, Bhat KG (2020) Effect of curcumin on growth, biofilm formation and virulence factor gene expression of Porphyromonas gingivalis. Odontology 1:148-156

28. Patil SM (2013) Development of UV spectrophotometric method for estimation of letrozole in pure and pharmaceutical dosage form. Indo Am J Pharm Res 2(6):2345-2353

29. Patil SM (2013) Development of validated UV spectrophotometric method for estimation of fosfestrol in bulk and pharmaceutical dosage form. World J Pharmaceutical Res 3(7):5541-5548

30. Balasaheb AK, Subhash TR (2015) Development and validation of UVspectrophotometric method for estimation of dolute gravirsodium in tablet dosage form. Malaysian J Analytical Sci 19:67-78

31. Pankti DP, Kusum MS, Mehul PK (2013) Development and validation of UVvisible spectrophotometric method for simultaneous estimation of momentasone furoate, hydroquinone and tretinoin from their pharmaceutical dosage form. Int J Pharmaceutical Sci 49:296-300

32. Dhartarkar PG, Kalamkar RV, Saoji SD (2011) Development and validation of UV spectrophotometric method for estimation of dexibuprofen in bulk and dosage form. Scholars Res Library Pharmaceutical Chem 3:361-366 
33. Kamboj AS, Jain UA (2017) Development and validation of UV spectroscopic methods for simultaneous estimation of salbutamol sulphate and doxophylline in combined solid dosage form. Int J Pharmaceutical Sci 9: $117-122$

34. Patil A, Patil S (2014) UV, FTIR, HPLC confirmation of camptothecin an anticancer metabolite from bark extract of Nothapodytes nimmoniana ( $($. Graham). Am J Ethnomedicine 1(3):174-185

35. Puri SC, Bhat BA (2005) Separation of 9-Methoxycamptothecin and camptothecin from Nothapodytes foetida by semipreparative HPLC. J Chromatographic Sci 43(1):348-350

36. Ramesha BT, Amna T, Ravikanth G (2008) Prospecting for Camptothecines from Nothapodytes nimmoniana in the Western Ghats, South India: Identification of high-yielding sources of camptothecin and new families of camptothecines. J Chromatographic Sci 46(1):362-368

37. Chia-Ying LI, Chung-Hua LIN, Tian-Shung WU (2005) Quantitative Analysis of Camptothecin Derivatives in Nothapodytes foetida Using 1 H-NMR Method. Chem Pharm Bull 53(3):347-349

38. Krishnan P, Mariappan R (2016) Efficiency of newly formulated camptothecin with $\beta$-cyclodextrin- EDTA-Fe ${ }_{3} \mathrm{O}_{4}$ nanoparticle conjugated nanocarriers as an anticolon cancer (HT29) drug. Sci Rep 7:10962

\section{Publisher's Note}

Springer Nature remains neutral with regard to jurisdictional claims in published maps and institutional affiliations.

\section{Submit your manuscript to a SpringerOpen ${ }^{\circ}$ journal and benefit from:}

- Convenient online submission

- Rigorous peer review

- Open access: articles freely available online

High visibility within the field

- Retaining the copyright to your article

Submit your next manuscript at $\boldsymbol{\nabla}$ springeropen.com 